原

\title{
胃粘膜下腫瘍（非上皮性腫場）の臨床的検討
}

\author{
北海道人学医学洲第 1 外科

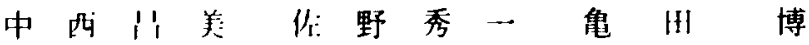 \\ 葽 西 洋
}

市立札幌苪院外科 長谷川 正：義

\section{CLINICAL STUDY ON GASTRIC SUBMUCOSAL TUMOR}

Yoshimi NAKANISHI, Hidekazu SANO, Hiroshi KAMEDA and Yoichi KASAI

1st Department of Surgery, Hokkaido University School of Medicine

Masayoshi HASEGAWA

Department of Surgery, Sapporo Municipal Hospital

1980年まで数室で経験した胃腫瘍826例の中で，胃粘膜下睡場は31例，3.9\%を占め た，そのうち，良性腫瘍は 8 例，悪性腫場が23例（74\%）であった，組織診断は，良性 例では平滑筋腫，平滑筋芽腫，悪性例では悪性 リンパ腫，平滑㬳肉腫，悪性平滑節芽腫 などであった，術前の診断をみると，全体の $54.8 \%$ が胃粘膜下睡場と疑診または確診さ れている。悪性リンパ腫10例の術前正診率は10\%，非リンバ性悪性腫場12例では92\%と， 悪性リンパ畽はきわめて低い正診率を示した，診断の根拠となった検査別正診率をみる と，胃透視が $14 \%$ ，胃内視鏡が $20 \%$ と低率であるのに対し，血管造影では78\%と高い術 前正診率を示した，病理組織学的には，畽瘍 $5 \mathrm{~cm}$ 以上, 多発する病変, 粘膜面の変化, 浆膜への浸潤などは，悪性を疑わす所見であり，悪性リンパ腫は漬愓形成，非リンパ性 肉腫は脐形成を伴ならことが多い。リンパ節転移は，悪性リンパ腫で $82 \% ，$ 非リンパ性 肉尰で $45 \%$ が転移陽性で，平滑㬳肉腫，悪性平滑筋芽腫ではすべて $\mathrm{n}_{2}$ 以下のリンハ節転 移であった，手術術式は胃癌に準した $R_{2}, R_{3}$ ，または simple gastrectomy を行った．予

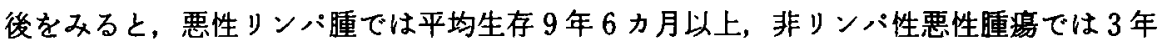
6 カ月以上であった。

以上より次の結論をえた。

術前診断には血管造影が有用で, とくに非リンパ性肉尰に対しては診断的価値が高い。

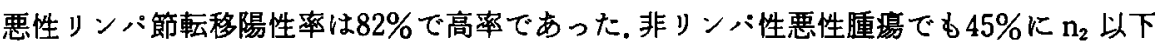
のリンパ節転移陽性を認め, $\mathrm{R}_{2}, \mathrm{R}_{3}$ の積極的リンパ節廊清が必要と考えられた。悪性り ン八腫は平均生存期間が 9 年 6 カ月以上と非リンパ性悪性腫蕩に比し予後が良好であっ

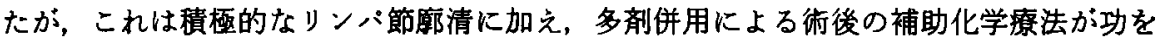
奏したためと思われる。

\section{I はじめに}

胃に発生する非上皮性腫痬は胃癌にくらべると，そ の発生頻度はきわめて少ない，しかし，その発生母地 は筋組織，血管系組織など多岐にわたり，多様な病態 像を呈することが多い，したがって，術前に確定詥断
されることが少なく，とくに良性が悪性かの鑑別は困 難であって，術式の選択に苦虑することが多々ある。 今回われわれは教室で経験した胃粘膜下睡晹につい て，とくに術前診断の向上の点から検討した，その結

果, 2,3 の知見をえたので, 興味ある 2 症例を含め 
て報告する。

\section{II 病態と外科治癔}

\section{1。発生頻度およU分類}

1964年から1980年までの 17 年間に北大第 1 外科で経

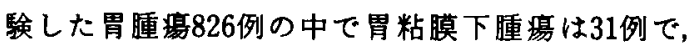
$3.7 \%$ であった。そのうち，良性腫湯は 8 例，悪性腫場 が23例で悪性例が全体の74\%を占めている．その組織 診断は, 良性例では平滑筋腫 ( 3 例), 平滑筋芽尰 (2 例), 脂肪腫 ( 1 例), 好酸球性肉芽腫 ( 1 例), 沪胞性 リンパ胞（1 例）などであるか，悪性例では悪性リン 八腫 (11例)，平滑筋肉腫 ( 6 例)，悪性平滑筋芽腫 ( 4 例)，カルチノイト (1 例), 血管内皮腫（1例）など であった（表 1 ).

\section{2. 性, 年龄分布}

胃粘膜下畽場全例の男女比は1.38対 1 の割合で，良 性腫瘍では性差はみられないが, 悪性腫湯では男性14, 女性 9 で男性に多かった。

\section{表 1 胃粘膜下重禹の組織診断}

\begin{tabular}{|c|c|}
\hline I & 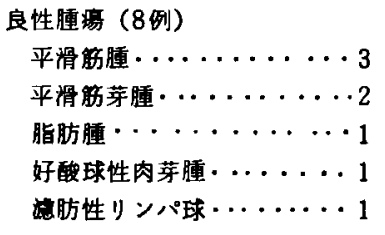 \\
\hline & 計 \\
\hline II & 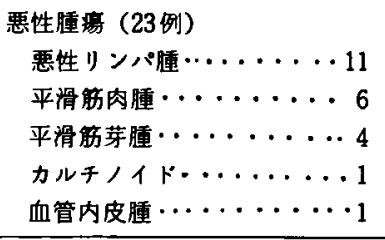 \\
\hline & 計 \\
\hline
\end{tabular}

\section{表 2 胃粘膜下腫暚の年齡分布}

\begin{tabular}{c|c|c|c}
\hline 年令（才） & 良性腫富 & 悪性腫場 & 計 \\
\hline $20 \sim 29$ & 0 & 2 & 2 \\
\hline $30 \sim 39$ & 2 & 1 & 3 \\
\hline $40 \sim 49$ & 0 & 6 & 6 \\
\hline $50 \sim 59$ & 4 & 3 & 7 \\
\hline $60 \sim 69$ & 2 & 11 & 13 \\
\hline 計 & 8 & 23 & 31 \\
\hline
\end{tabular}

年龄分布をみるて，最年少が22歳，最年長が69歳と 年齢層は広いか，年代別にみると60藏台が全体の $42 \%$ を占めている，また良性，覀性の比では，20歳台から 50 歳台までは，とくに若年層に良性例が多いとい5傾 向はみられないが，60歳台では85\%が悪性例であった ことが特徵的であった（表 2 ).

\section{3. 術前診断}

術前の診断で, 全体の $54.8 \%$ が胃粘膜下腫漡と疑診 または確診されているが，良性睡湯 8 例では，胃粘膜 下腫湯と診断されたのは25\%, 平滑肪腫と診断された のが25\%で，はかに平滑筋肉腫，胃癌，胃潰瘍，肝癌 などの診断があげられる。良性，悪性の鑑別は別にし て粘膜下腫場之診断されたものが 8 例中 5 例， $63 \%$, 質的猃断として良性の胃粘膜下腫瘍と診断されたるの が 8 例中 2 例， $25 \%$ である.

覀性リンバ腫10例についてみると，胃癌と診断され たものが 7 例, 以下胃肉腫, 食道癌, 胃ポリープと診 断されたすのがそれぞれ1例ずつあり，粘膜下畽湯と しての正診率は $10 \%$ ，質的な正診率む10\%できわめて 低率である。

これに対し，非リンパ性悪性腫煬では12例の5ち, 胃肉腫と診断されたものは 9 例で，そのはか胃粘膜下 畽場、平滑筋腫, 胃癌などが各 1 例ずつあり，12例中

\section{表 3 胃粘膜下堙堨の術前診断}

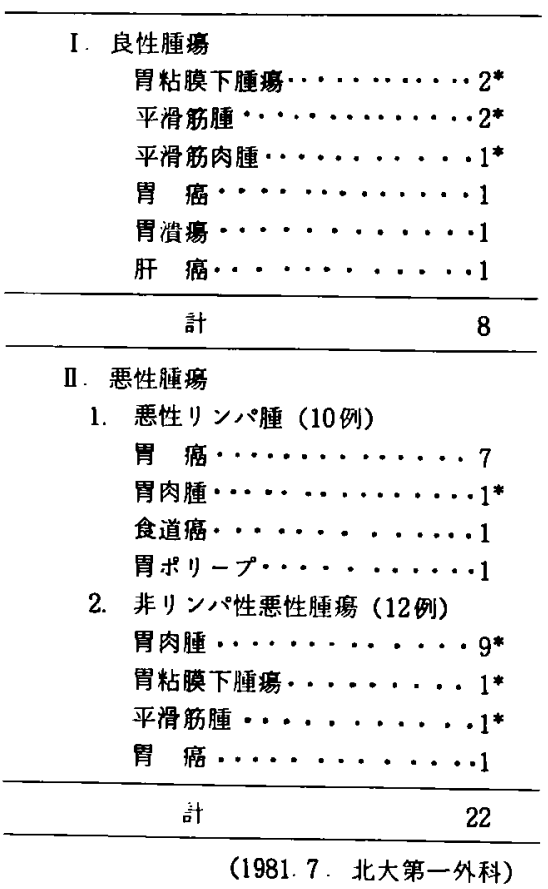


では92\%が街前に胃粘膜下腫瘍と診断されている，質 的な正診率も12例中 9 例，75\%であっても悪性リンパ 腫にくらべると, 術前の確診率はきわめて高い(表 3 ).

術前診断の根拠となった検查法のうち胃透視による ものが 7 例ではその正診率は14\%，胃内視鏡によるも の 4 例では20\%でいつれる低率である.. しかし，血管 造影によるもの 9 例では78\%が術前に診断されている （表 4 ），血管造影に上る術前診断の偽陽性は胃癌の診 断が悪性リンバ腫であり，肝癌の診断が平滑筋腫で あった例の 2 例である。

\section{4. 病理学的所見}

切除標本からえられた所見を各因子別に検討し，次 の結果をえた。

\section{1）腫嘴の大きき}

良性腫場では径 $3 \mathrm{~cm}$ 以下のものが大部分であるの に対し，悪性リンパ腫では $80 \%$ が佳 $5 \mathrm{~cm}$ 以上の大きさ で,径 $3 \mathrm{~cm}$ 以下のすのはわずか10\%であった。非リン パ性悪性尰瘍でも $75 \%$ が径 $5 \mathrm{~cm}$ 以上の腫瘍で，中には $20 \times 15 \times 8 \mathrm{~cm}$ という巨大平滑筋肉腫もあった（表 $5)$.

\section{2）腫满占居部位}

良性腫場はすべて 1 区域または 2 区域に限局してい るが，悪性腫芴では23例中26\%が AMCにわたるもの

表 4 術前検查とその正診率

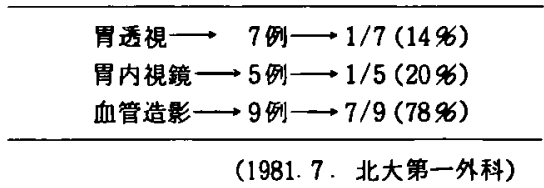

表 5 胃粘膜下腫璤の大きさ

\begin{tabular}{|c|c|c|c|c|c|}
\hline & & $0 \sim 3$ & $3 \sim 5$ & $5 \sim$ & 計 \\
\hline I. & 良性腫瑒 & 6 & 0 & 1 & 7 \\
\hline \multicolumn{6}{|c|}{ 口. 悪性腫場 } \\
\hline & 悪性リンパ腫 & 1 & 1 & 8 & 10 \\
\hline & 平滑筋内嗹 & 1 & 1 & 4 & 6 \\
\hline & 平滑筋芽腫 & 1 & 1 & 2 & 4 \\
\hline & カルチノイド & & & 1 & 1 \\
\hline & 血管内皮腫 & & & 1 & 1 \\
\hline & (不明) & & & & (2) \\
\hline & 計 & 9 & 3 & 17 & $29(2)$ \\
\hline
\end{tabular}

表 6 粘膜下胵㻦の占居部位

\begin{tabular}{|c|c|c|c|c|c|}
\hline & A & $M$ & C & AMC & 竍 \\
\hline I．良性腫霰 & 3 & 3 & 2 & 0 & 8 \\
\hline II . 悪性腫楊 & & & & & \\
\hline 覀性リンパ腫 & 3 & 2 & 2 & 4 & 11 \\
\hline 平滑筇肉㯵 & 3 & 1 & 1 & 1 & 6 \\
\hline 平滑别芽䐈 & 2 & 1 & 0 & 1 & 4 \\
\hline カルチノイド & 1 & & & & 1 \\
\hline 血管内皮腫 & & 1 & & & 1 \\
\hline 計 & 12 & 8 & 5 & 6 & 31 \\
\hline
\end{tabular}

(1981.7. 北大一第外科)

表 7 胃粘膜下腫重の粘膜面の变化

\begin{tabular}{|c|c|c|c|c|}
\hline 粘膜面の変化 & 整 & 潰場 & 胳形成 & 計 \\
\hline I，良性腫渴 & 5 & 2 & 1 & 8 \\
\hline \multicolumn{5}{|l|}{ II. 悪性腫煬 } \\
\hline 悪性リンパ腫 & 0 & 8 & 0 & 8 \\
\hline 平清筇肉腫 & 1 & 0 & 5 & 6 \\
\hline 平滑筇芽腫 & 2 & 2 & 0 & 4 \\
\hline カルチノイド & 0 & 1 & 0 & 1 \\
\hline \multicolumn{5}{|l|}{ (不明) } \\
\hline 計 & 8 & 13 & 6 & $27(4)$ \\
\hline
\end{tabular}

であったとくに，覀性リンバ腫では11例中36\%のも のが全胃を占め，1区域に限局する場合です多発性の むのが多かった（表 6 ）。

\section{3）粘膜面の变化}

良性腫湯では粘膜面の乱れが少ないのに対し，悪性 腫瑒では潰瘍，刘形成などの変化を示すことが多い． とくに，悪性リンバ揰では全例に演掦形成を伴らこと が特徽的であった，また，平滑筋肉腯では 6 例中 5 例 に䐗形成を認め, 覀性リンパ腫の場合とはことなって いた（表 7 ).

\section{4) 浆膜面の変化}

悪性腫瘍では19例中， $53 \%$ に $\mathrm{S}_{2}$ または $\mathrm{S}_{3}$ の高度な 采膜浸潤例が認められたが, $\mathrm{S}_{\mathrm{S}}$ 症例の浸潤荿器は䐙, 結腸，肝などが主である（表 8 ）。

5）リンパ節転移

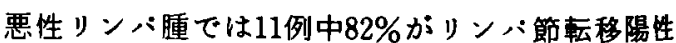
で，非リンパ性悪性腫埸のリンパ節転移陽性率 $45 \%$ に くらべると高率で，しかる㽻範囲であることる特䍃的 


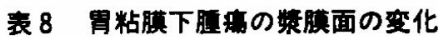

\begin{tabular}{|c|c|c|c|c|c|}
\hline 浆瞙面の変化 & $s_{0}$ & $s_{1}$ & $s_{2}$ & $s_{3}$ & 計 \\
\hline I . 良性腫焬 & 8 & 0 & 0 & 0 & 8 \\
\hline \multicolumn{6}{|l|}{ II. 悪性腫瘍 } \\
\hline 悪性リンパ腫 & 3 & 0 & 4 & 2 & 9 \\
\hline 平滑脅肉腫 & 3 & 0 & 1 & 2 & 6 \\
\hline 平滑筋芽嗹 & 3 & 0 & 0 & 0 & 3 \\
\hline カルチノイト & 0 & 0 & 0 & 1 & 1 \\
\hline （不明） & & & & & (4) \\
\hline 計 & 17 & 0 & 5 & 5 & $27(4)$ \\
\hline
\end{tabular}

表 9 胃粘膜下厓瑀のリンパ節転移

\begin{tabular}{|c|c|c|c|c|c|}
\hline リンパ節軽移 & $n_{0}$ & $\begin{array}{c}\mathrm{n}_{1} \\
(+)\end{array}$ & $\begin{array}{c}n_{2} \\
(+)\end{array}$ & $\begin{array}{c}\mathrm{n}_{3} \\
(+)\end{array}$ & 計 \\
\hline I．良性腫烧 & 8 & 0 & 0 & 0 & 8 \\
\hline \multicolumn{6}{|l|}{ II. 悪性腫㛫 } \\
\hline 悪性リンパ腫 & 2 & 2 & 5 & 2 & 11 \\
\hline 平滑筋肉腫 & 3 & 2 & 1 & 0 & 6 \\
\hline 平滑筋芽腫 & 3 & 1 & 0 & 0 & 4 \\
\hline カルチノイト & 0 & 0 & 0 & 1 & 1 \\
\hline (不明) & & & & & (1) \\
\hline 計 & 16 & 5 & 6 & 3 & $30(1)$ \\
\hline
\end{tabular}

であった．平滑筋肉尰，平滑筋芽腫の場合のリンパ節 転移はすべて $\mathrm{n}_{2}$ までに留まっていた（表 9）.

\section{5. 外科治恶と予後}

手術術式は, 良性腫腫瘍に対しては胃部分切除（1 例)，幽門側胃切除（5 例)，胃全摘（2 例）などであ る.悪性リンパ腫に対しては幽門側胃切除 ( 7 例), 胃 全摘（ 3 例）などで, 試験開腹のみが 1 例である. 非 リンパ性覀性腫瘍に対しても胃広沉切険が主である が，幽門側胃切除 9 例のらち 3 例は結腸，䐙または肝 の合併切除を行ない, 胃全摘3例中 2 例は脾合併切除を 行なっている(表10).

悪性腫暍例の5ち直死例，不明例を除いた12例の予 後を検討すると，悪性リンバ腫では 9 カ月死亡, 8 年 生存, 12 年生存, 12 年生存, 15 年生存の 5 例で, 最短 生存 9 力月, 最長生存15年生存中となり, 平均生存期 間は 9 年 6 カ月以上である. 非リンパ性悪性腫湯では
表10 胃粘膜下堙理に対する手術々式

\begin{tabular}{|c|c|c|c|c|c|}
\hline 垁㭧 & $\begin{array}{l}\text { 胃部分 } \\
\text { 切 除 } \\
\end{array}$ & $\begin{array}{l}\text { 幽門側 } \\
\text { 切 除 } \\
\end{array}$ & 周全摘 & $\begin{array}{l}\text { 武験 } \\
\text { 開腹 } \\
\end{array}$ & 計 \\
\hline I．良性腫楊 & 1 & & 2 & 0 & 8 \\
\hline \multicolumn{6}{|l|}{ II. 悪性腫清 } \\
\hline 悪性リンパ腫 & 0 & & 3 & 1 & 11 \\
\hline $\begin{array}{l}\text { 韭リンパ性 } \\
\text { 覀性腫㻛 }\end{array}$ & 0 & $9(3)$ & $3(2)$ & 0 & $12(5)$ \\
\hline 計 & 1 & $21(3)$ & $8(2)$ & 1 & $31(5)$ \\
\hline
\end{tabular}

2.5 力月死亡, 1 年 6 力月生存, 1 年 9 力月生存, 3 年 生存, 3 年生存, 4 年生存, 11 年死亡の 7 例で, 最短 平存は2.5力月, 最長生存は11年, 平均生存期間は 3 年 6 力月以上となる. 術後 2.5 月 月で死亡した症例は平滑 筋肉隀の肝転移例で，胃切除と肝合併切除を行なった が, 術後腫瘍再発により死亡した。

III 術中診断の困難であった症例

術後、術中の診断が困難であった 2 症例がある.

症例 1 S.F. 37y.o. 女

術前の胃バリウム検査にて，胃体部から前庭部にか けての圧排像がある(図 1 )，腹腔動脈造影所見では静 脈相で左肝動脈領域に tunor stain, 走行不整, 断裂像 があり肝腫瘍と診断された，手術所見では，畽場は小

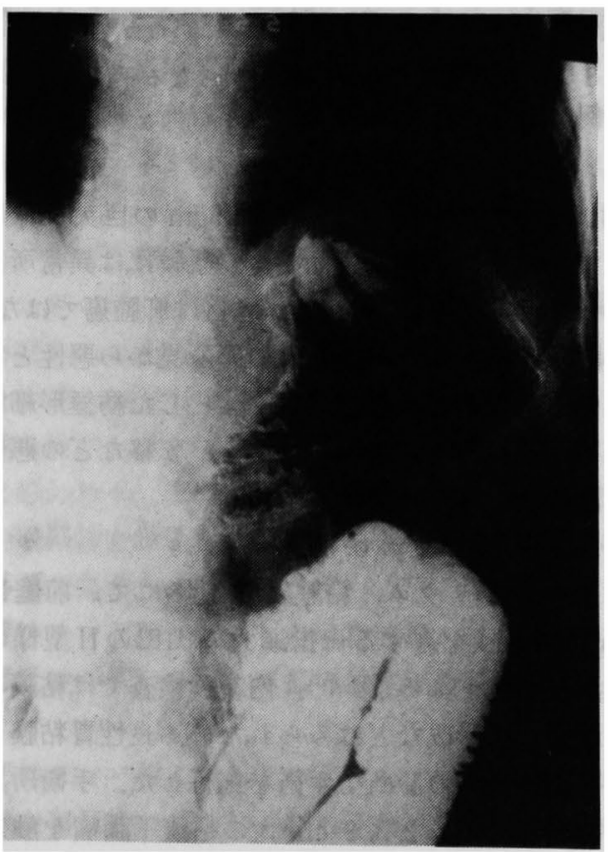

図1胃体部から前庭部にかけての圧排像を認める (症例 1) 


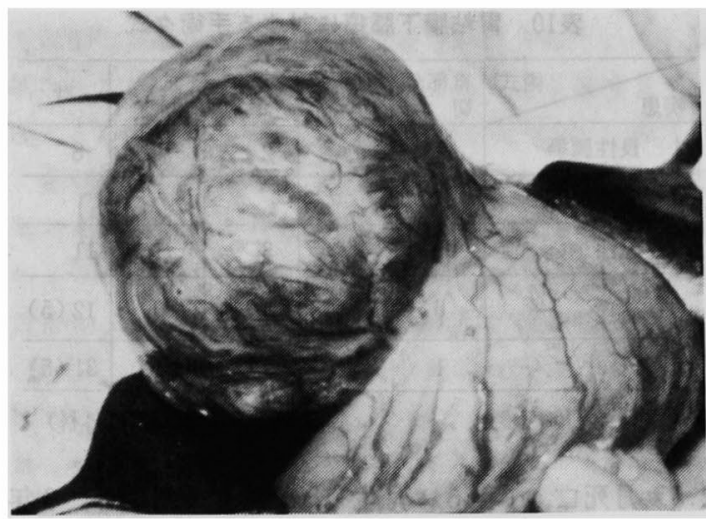

図 2 小弯側より胃外性に発青した径 $15 \mathrm{~cm}$ の球形腫 痸 (症例 1 )

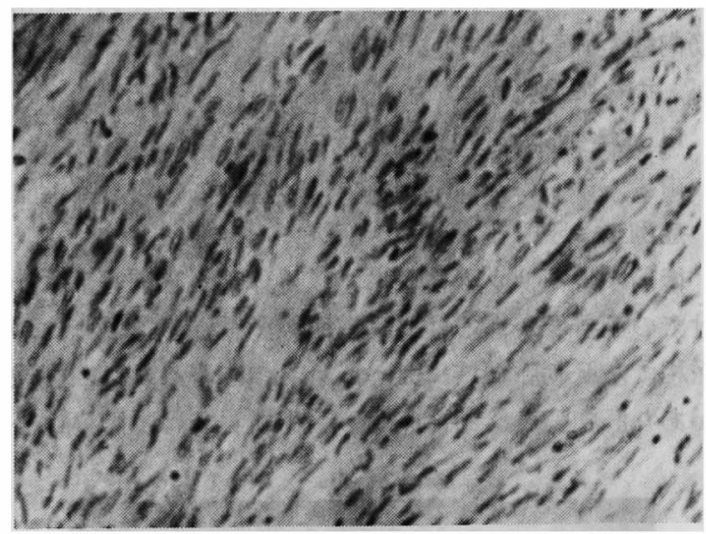

図３よく分化した紡鏩形細胞からなる平滑筋腫（症 例 1)

弯側より胃外性に発育し，直径 $15 \mathrm{~cm}$ の巨大な球形を 呈していたか，腫瘍の表面を覆ら浆膜には異常所見は なかった(図 2).したがって, 本例は肝腫瘍ではなく， 胃粘膜下腫瘍であるか，血管造影所見から悪性と考兄 られた。病理組織所見は，よく分化した紡錘形細胞か らなる平滑筋尰で, 核分裂やリンバ転移などの悪性所 見は認めなかった（図了）,

\section{症例 2 I. S. 62 y. o. 男}

術前の胃バリウム, 粘膜 2 重造影にて, 前庭部に bridging fold を有する母指頭大の山田の II 型様の隆 起性病変をみとめる(図 4 ). 内視鏡検査では粘膜の不 整，潰瘍，脐形成などはみられない，良性胃粘膜下腫 瘍 (平滑筋腫) の診断で手術を施行した。手術所見で は，前庭部後壁に $2 \times 2 \mathrm{~cm}$ 大の粘膜下畽瘤を触知し たが， $\mathrm{S}_{0}$ で腫瘤に不規則性はなく，また，リンパ節腫

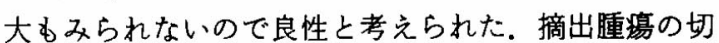

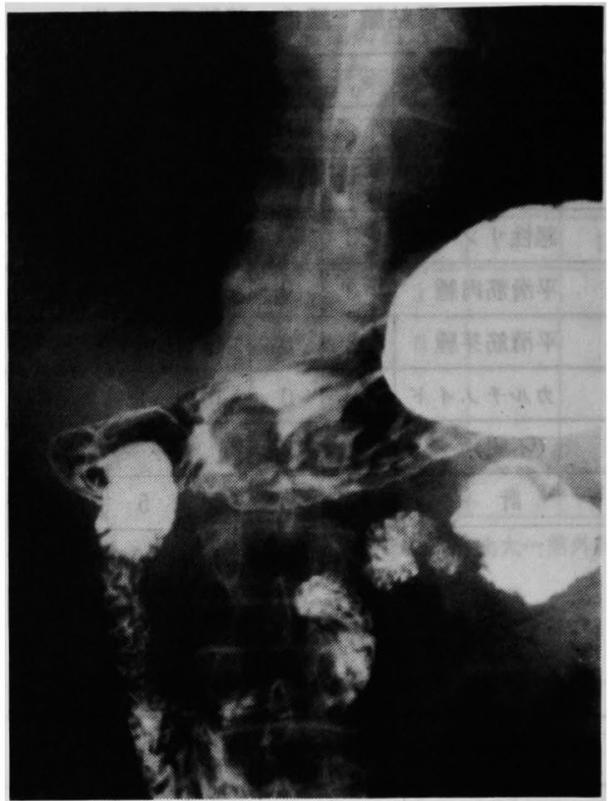

図 4 症例 2.I.S.62yo.m.胃バリウム所見 前庭部に bridging fold を有する山田の II 型様の隆 起性病変を認める（症例 2)

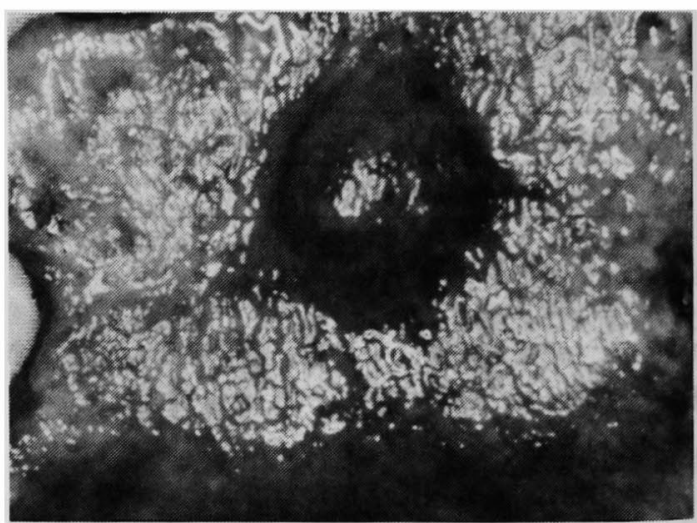

图 5 图 4 と同一症例, 切除柡本 前庭部後壁に $2 \times 2.5 \mathrm{~cm}$ の粘膜面平滑な腫瘤を認 めた（症例 2 )

除標本では $2 \times 2 \times 2.5 \mathrm{~cm}$ の粘膜面, 将膜面とすに異 常のない，表面平滑，割面均一の腫瘤であった(図 5). 組織像では，腫場細胞は核周囲透明帯を有する円形な いし多角形細胞からなり，核濃染，核分裂像および䋦 層への浸潤像もみられ悪性平滑筋芽腫と診断された (図6).

症例 1 は, 術前に血管造影所見などから肝属瘍と診 断され，手術所見にて悪性の胃粘膜下腫瘍之診断，胃 


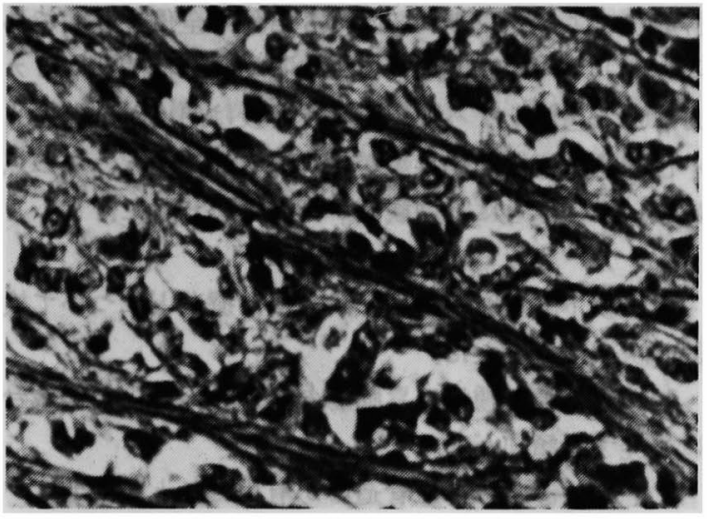

図 6 図 4 と同一症例，切除標本 核周囲透明带を有する円形ないし多角形の腫湯細胞 を認め，核濑染，核分裂像より悪性平滑筋芽腫と診 断された（症例 2)

切除に加えリンパ節郭清を行なったが，術後の病理所 見で平滑筋腫と診断された。本症例は，開腹した時点 で，胃小弯側から発生した粘腫下腫瑒として，悪性の 場合も考虑した術式を選択した。

症例 2 は, 術後の病理所見によって悪性平滑筇芽腫 と診断されたもので，術中の組織診の必要性，摘出腫 瘍の詳細な観察の重要性を痛感させられた，幸い本症 例は, 術後 4 年を経過しても再発の所見はなく社会復 㷌している。

\section{IV 考察}

胃粘膜下腫煬の胃腫煬全体に占める割合は当科では 3.7\%であり，そのうち胃肉腫の胃腫場全体に対する頻 度をみると，当科では $2.1 \%$ となる。佐野ら9の報告し た $2 \%$, 高木ら"の $1.5 \%$ とは注同様の発生頻度を示し ている。しかし, Marshall らは $5.7 \%$, Ochsner $5^{12)}$ は3.5\%をあげて拈り，欧米では胃粘膜下腫湯の発生頻 度が高いようである。しかし，これは，本邦では胃癌 の発生率が高いため胃肉腫の占める割合が少ないとい ら結果になったとも考えられる。

年齢別頻度では，われわれの症例では60歳台が $42 \%$ であり，70歳以上の症例がないことからも，この年代 が好発年齢層と考えられる．佐野ら91450歳台に多い としているが，われわれの例では良性胃腫瘍 8 例中 4 例が50歳台に発生しており，良性腫堭については発生 頻度が高いといら傾向がみられたが，これは全体的に は顕著ではない。

性別では，男女比は1.38：1 と男性にゃや多い傾向 がみられ, 山本ら5の悪性リンパ腫で $3: 2$, 平滑筋肉
腫で 1：1といら報告とほぼ同様な結果である。

最近は胃集団検診の普及, 各種診断技術の進歩に伴 ない, 胃粘膜下腫瘍の術前診断率も向上しつつあるが, 良性悪性の鑑別も含めて術前に質的診断が確立される 例は少ないよ5に思われる，われわれの検索でも，良 性悪性の鑑別を含めた質的な正診率は，35\%と低率で ある。.とくに悪性リンバ腫の場合は，はとんどが術前 には胃癌と診断され，病理組織検査で初めに悪性リン 八腫と診断されることが多い，しかし，非リンバ性の 肉腫では術前の正診例が多く，術式の選択を容易にし ている，術前の異診例は，ほとんど胃透視や胃内視鏡 検査によるものであった。一般的には，腹腔動脈造影 所見では，腫瘍が主として胃に分布する血管によって 栄養されていること,血管に富みしかる不規則な走行， 断裂および変化がみられることなどが悪性と診断する 根拠となっている．血管造影です正診がえられなかっ た例をみると，悪性リンパ腫の場合は tumor stain 等 の明らかな悪性像所見に乏しいことが確診を困難にす ること，良性の筋腫です tumor stain 様の陰影を認め ることがあるなどの点に留意すべきであろう。さらに は腫湯の被膜の整，不整，実質性であるか否か，内部 の均一性, 発生器の鑑別などの判定には, 超音波検査, CT スキャンが有効であると思われる.

切除標本からえられた所見では, 径 $5 \mathrm{~cm}$ 以上の腫瘤 では悪性例が多いこと，広汎な病变，多発する病巣を 有する場合は悪性例とくに悪性リンパ腫が多いこと, 粘膜面の变化で潰瘍を呈する増合は悪性リンハ腫, 脐 形成を認めるときは非リンパ性肉腫が多くみられるこ と，悪性リンパ腫ではリンパ節転移陽性率が高いこと などが重要な鑑別点になると考えれた。

したがって，術前の胃透視，内視鏡にて胃粘膜下腫 埸が疑われる場合は，血管造影を行ない悪性所見の有 無を検索，さらには超音波検査， CT スキ+ンによる形 態的な検討を進めることも正診率をたかめる5えに有 効と思われる．また，術中に悪性が疑われるときは， 術中組織診を積極的に行ならことが重要で, 予め準備 が必要であろう。

悪性リンパ尰以外のものは放射線, 化学療法に対し て感受性が低いので，本症の治療は外科手術が主であ る.

悪性リンパ腫に対しては, リンパ節郭清を伴なら胃 切除を可及的に行ない，根治手術不能に対しては積極 的な化学療法, 放射線治療が補助治療として有効され る. 
悪性リンバ畽では，多発する小病巣が広汎に散在す る傾向があるので，摘出胃を入念に検索し残胃に病変 のないことを確認する必要がある。また，本症のリン

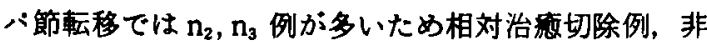
治革切除例が多くなるので，術後の化学療法，放射線 治療など補助寮法の計画をたてる必要がある。

平滑筋肉腫に対しては, リン八節郭清の是非が問題 となる. 胃平滑筋肉種のリンバ節転移率は, Mershall ${ }^{2}$ $0 / 20$ (0\%), Berg ${ }^{3)} 1 / 24$ (4.2\%), 梶谷4) $1 / 6$ (16.7\%), 佐野5) $0 / 14(0 \%)$, 中野6) $3 / 11(27 \%)$ と胃癌にくらべ転移陽性例は少ない。したがって, Marshall, Berg らは念入りなりンバ節郭清の不必要 を主張している，しかし，われわれの検討では，6例 中 3 例 (50\%) にリンハ節転移を認めており，われ われは肉眼的にる転移がみられない場合でる積極的に リンバ節郭清を行なら方針である。また。非リンパ性 肉腫のリンバ節転移はすべて $\mathrm{n}_{2}$ までに留まっており， たとえ他臓器への直接浸潤がっても合併切除 $+R_{3}$ にて根治手術可能性が多いことを示している.さらに， 肝転移例についても，転移病巣が一葉に限局している ときは，肝葉切除の適応と考之，拡大手術により根治 性を高める期待がある。

本症の予後は比較的に良好で，悪性リンパ睡で試呀 開腹を除き, $\mathrm{n}_{3}(+)$ の症例む含め全例生存中である. 大ら"は61.4\%にリ 7 バ節転移をみとめ，3 年生存率 $23.1 \%, 5$ 年生存率 $16.7 \%, 10$ 年生存率 $7.0 \%$ とし，高 木ら"によると, 全体の 5 年生存率が 44 例中18例, $41 \%$ ，相対非治复までを含む根治手術例の 5 年生事山 24例, 55\%である。ささらに高木ら"1 Sm までに止まる 早期悪性リンバ腫は 5 年生存率が $90 \%$ で，リンバ節転 移陽性例においても75\%であるのに対し，pm 以上の 進行例では 5 年生存率ば $39 \%$ であり，リン八節転移お よび浸達度が予後に関係深く，積極的なリンバ節郭清 の必要性を強調している。ささらに下山らクは多剂併用 による化学療法の効果を報告し，とくにCyclophosphamide, Vincristine, Adriamycin, Predonisolone $の$ 4 骩を併用する VEPA 療法により，根治手術不能例で あっても近年は治療成積が向上しつつあるといら。

胃平滑筋肉腫についてては，大井ら》は54.3\%に転移 を認め, 3 年生存率 $63.6 \%, 5$ 年生存率 $44.4 \%, 10$ 年年 生存率 $28.6 \%$ 之述へ，佐野ら”は全例リンバ節転移は ないが，14例35.7\%に肝転移を認め，大きな潰瘍を伴 ない，かっ胃外性に発育しているすのは予後が悪いと している. 当科では術後肺炎, 心不全による直死 2 例,
肝転移による死亡 1 例を除く 3 倍例ら全例生存中であ る. 非リンハ性要性㻛全体では平均生存期間 3 年 6 力 月以上と悪性リン八腫にくらぺ予後仕悪いが，非リン 八性厘偒は術後経過年数が短かいるのが多く，この点 についてはさらに長期観察が必要と思われた。

\section{$\mathrm{V}$ おわりに}

胃粘膜下腫場31例の病態，外科治療などについて検 討し次の知見をえた。

1）胃粘膜下腫瘍は胃腫瘍の3.7\%にみられ,60葴台 に好発する傾向がある。

2）術前猃断には血管造影が有用で，とくに非リン 珄肉尰に対しては診断的価値が高い。

3）腫場が径 $5 \mathrm{~cm}$ 以上の のの, 全胃を占める病変, 多発する病巣，粘膜面の变化，浆膜漫潤などは，悪性 の所見である。 また，粘膜面の変化では，悪性りンハ 睡は潰瘍形成，非リンパ性肉畽は脐形成を伴らことが 多い。

4）非リンバ性肉腫ではリンバ節転移陽性例におい ても $\mathrm{n}_{2}$ 以下に留まり,他葴器漫潤例です払大手術可能 例が多い。

5）悪性リンバ腫は平均生存期間が 9 年 6 カ月以上 で非リンバ性悪性腫痬に比し予後は良好であった。

\section{文献}

1）高木国夫, 山本英昭, 岸本秀婎他：胃垔性リンバ 尰の手術的治療上成綨。胃と腸，16：493-501, 1981.

2) Marshall, Samuel F. and Meissner, William A. : Sarcoma of the stomach. Annales of Surgery, $131: 824-837,1950$.

3) Berg, John and McNeer, Gordon : Leiomyosarcoma of the stomach. Cancer, $13: 25-33,1960$.

4）暒谷 銀，渡辺 弘，高木国夫他：原発泩胃肉隀 について。鹰の臨床, $6: 141-151,1960$.

5）山本 浩，吉川㤸蔵，北国久三他：胃に発生した 非上皮性腫斬の臨床的ならびに病理学的考察。外 科, $32: 876-886,1970$.

6）中野 博，成欢富雄，早川 勝他：原発性胃肉重 18例の検討. 外科，32：935-941，1970.

7）大井 実, 三穂乙実, 尹東 保他：非癌性胃盾素。 外科, $29: 112-133 ， 1967$.

8）下山正德，吉田茂昭，綮輔他：胃悪性リンパ 腫の化学療法。胃之腸，16：503-517，1981.

9）佐野量造，広田映五，下田忠和他：胃肉睡の病理. 胃と腸，5：311-321，1970.

10）小池䌊男，桜井道郎，藤田ひろ子他：信州大学第 
2 外科で経険した胃肉腫の外科臨床的㭘討. 外科, 43 : 159-162, 1981.

11）村本達雄，佐野秀一，中西昌美他：胃外型発育を 呈した巨大胃平滑筋肉尰の 1 例. 北海道外科雑誌,
$24: 31-34,1979$.

12) Ochsner, S. and Ochsner, A.: Sarcoma of the stomach. Ann. Surg., $142:$ 840, 1955. 